\title{
CRITERIA FOR SPORT SELECTION OF 15-16-YEAR-OLD CYCLISTS
}

\author{
Ivan Kolev, Latchezar Stefanov \& Daniela Aleksieva \\ National Sports Academy "Vassil Levski", Sofia, Bulgaria
}

\begin{abstract}
The improvement of sport achievements in cycling sports, as well as the enormous competition in the struggle for global hegemony, require continuous improvement in the quality and effectiveness of the training process. The aim of the following study is to establish statistically reliable criteria for sport selection in the age period 15-16-years. The object of the study is the physical development, physical training, technical and tactical skills of young cyclists from the Republic of Bulgaria. Research respondents are 20 boys practicing cycling in sport clubs in the country. The set of tests consists of 14 different tests (indexes) - $30 \mathrm{~m}$ from crouch start, 30 from standing start, $100 \mathrm{~m}$ from flying start, $200 \mathrm{~m}$ from flying start, $500 \mathrm{~m}$ starting from place, $1000 \mathrm{~m}$ starting from place, $2000 \mathrm{~m}$ starting from place, dynamometry - strong hand, dynamometry - weak hand, flexibility, height, standing long jump, weight and vertical jump. The indicators bring information on the anthropometric and motor abilities of the persons surveyed. To validate the statistical reliability of the selection set of tests at this age, two studies were performed. The results obtained are subjected to statistical processing by variation analysis and correlation analysis. The analyzed initial results give us reason to claim that the obtained information for statistical reliability of tests included in the set for 15-16-year-old cyclists is correct and therefore they have been chosen correctly. All tests included in the study are significant both for physical development, training and assessment of sport achievements of young cyclists. The results of the conducted survey can be used to update the training process in cycling, by specifying and individualizing the training parameters.
\end{abstract}

Key words: cycling, result, tests, development, research

\section{INTRODUCTION}

The improvement of sport achievements in cycling sports, as well as the enormous competition in the struggle for global hegemony, require continuous improvement in the quality and effectiveness of the training process (Dimitrova, 2001; Doychev, 2019). Cycling is a sport that has always been in the focus of spectators, athletes and sport specialists' due to its attractiveness, sport - with traditions and successes in Bulgaria, demanding high requirements for the athlete and his body, a sport that finds mass application among people from different ages and professions as a mean of physical development and psychological unloading (Doychev, 2019; Kolev, 2016; Doychev et al, 2009).

Unfortunately, there is still no methodology in place for objective measurement, systematization, justification and statistical reliability of specialized set of tests for sport selection and orientation of young cyclists.

The aim of the following study is to establish statistically reliable criteria for sport selection in the age period 15-16-years.

\section{METHODS}

The subject of the study is a system for sport selection and orientation, as well as the initial training of young cyclists.

The object of the study is the physical development, physical training, technical and tactical skills of young cyclists from the Republic of Bulgaria.

Research respondents are 20 boys practicing cycling in sport clubs in the country.

All tests included in the study are significant both for physical development, training and assessment of sport achievements of young cyclists.

The set of tests consists of 14 different tests (indexes) bearing information on anthropometric characteristics and motor abilities of respondents.

The obtained results are subject of mathematical and statistical processing:

- Variance analysis.

- Correlation analysis.

\section{RESULTS AND ANALYSIS}

Table 1 presents the average vales and variability of studied indexes included in the test set for the age 15-16-year-old cyclists during our first testing. 
Index $500 \mathrm{~m}$ standing start has average value of $\mathrm{x}=37,75 \pm 1,46 \mathrm{sec}$. and variance coefficient $\mathrm{V}=4 \%$. The relatively low variance coefficient value indicates that the group of 15-16-year-old cyclists is homogeneous in terms of their athletic and technical abilities.
The special speed abilities of cyclists measured using $200 \mathrm{~m}$ (flying start) with bicycle $(\mathrm{x}=6,53 \pm 0,63$ sec.) are the main expression of predisposition and development level of basic cycling ability - start speed of cyclists. The level of variance is $9 \%$ for the first index, and much higher for the second one (100 $\mathrm{m}$ from flying start) $-27 \%$.

Table 1. Variance analysis of studied indexes from the first testing - age group 15-16-year old cyclists.

\begin{tabular}{|l|c|c|c|c|c|c|c|c|}
\hline \multicolumn{1}{|c|}{ Index } & $\begin{array}{c}\text { Mea- } \\
\text { sured in: }\end{array}$ & $\mathbf{R}$ & $\mathbf{m i n}$ & $\mathbf{m a x}$ & $\mathbf{X}$ & $\mathbf{m}_{\mathbf{x}}$ & $\mathbf{S}$ & $\begin{array}{c}\mathbf{V} \\
\mathbf{( \% )}\end{array}$ \\
\hline 30 m from crouch start & $\mathrm{s}$ & 0,31 & 4,83 & 5,14 & 4,96 & 0,02 & 0,09 & 2 \\
\hline 30 m from standing start & $\mathrm{s}$ & 0,91 & 4,02 & 4,93 & 4,38 & 0,07 & 0,33 & 7,5 \\
\hline $\mathbf{1 0 0}$ m from flying start & $\mathrm{s}$ & 2,17 & 5,84 & 8,01 & 6,53 & 0,14 & 0,63 & 27 \\
\hline $\mathbf{2 0 0}$ m from flying start & $\mathrm{s}$ & 4,17 & 11,86 & 16,03 & 13,24 & 0,26 & 1,18 & 9 \\
\hline $\mathbf{5 0 0}$ m starting from place & $\mathrm{s}$ & 4,86 & 36,02 & 40,88 & 37,75 & 32 & 1,46 & 4 \\
\hline $\mathbf{1 0 0 0}$ m starting from place & $\mathrm{s}$ & 5,28 & 71,86 & 77,14 & 73,92 & 0,29 & 1,3 & 2 \\
\hline 2000 m starting from place & $\mathrm{s}$ & 11,83 & 161,15 & 172,98 & 166,14 & 0,75 & 3,38 & 2 \\
\hline Dynamometry - strong hand & $\mathrm{kg}$ & 5,4 & 43 & 48,4 & 46,64 & 0,29 & 1,33 & 3 \\
\hline Dynamometry - weak hand & $\mathrm{kg}$ & 4 & 43 & 47 & 44,94 & 22 & 1,02 & 2,26 \\
\hline Flexibility & $\mathrm{cm}$ & 3,2 & 5 & 8,2 & 6,94 & 0,23 & 1,03 & 15 \\
\hline Height & $\mathrm{m}$ & 14 & 161 & 175 & 166,55 & 0,88 & 3,93 & 2,35 \\
\hline Standing long jump & $\mathrm{cm}$ & 0,3 & 2,16 & 2,46 & 2,3 & 0,02 & 0,1 & 4,35 \\
\hline Weight & $\mathrm{kg}$ & 5,3 & 54,7 & 60 & 57,55 & 0,43 & 1,95 & 3,4 \\
\hline Vertical jump & $\mathrm{cm}$ & 13 & 35 & 48 & 41,3 & 0,79 & 3,55 & 8,5 \\
\hline
\end{tabular}

Indexes $1000 \mathrm{~m}$ and $2000 \mathrm{~m}$ starting from place are particularly important for assessing speed-strength endurance of young cyclists. They have average values for the first index $x=73,72 \pm 1,30 \mathrm{sec}$. and for the second $x=166,14 \pm 3,38$ sec. Table 1 presents the variance coefficients. From there is clearly visible that they are very low (2\%) and therefore the above indexes are stable and the studied population of 15-16-year-old cyclists at the start of the research period is homogeneous in terms of speed-strength endurance.

The lower limbs explosive strength abilities measured using the tests $30 \mathrm{~m}$ from crouch start with signal and $30 \mathrm{~m}$ from flying start are with average values $x=4,96 \pm 0,09 \mathrm{sec}$. and $\mathrm{x}=4,38 \pm 0,33 \mathrm{sec}$. and variance coefficients of $\mathrm{V}=2 \%$ for the first index and $\mathrm{V}=7,5 \%$ for the second. This is proof for high level of uniformity of studied sample.

Speed-strength abilities of lower limbs, measured using standing long jump and vertical jump have average value of $\mathrm{x}=2,30 \pm 0,10 \mathrm{~m}$ and $\mathrm{x}=57,55 \pm$ $1,95 \mathrm{~cm}$. The variance coefficient for these two indexes range between 6 - 7\% - objectively high level of uniformity.
The level of isometric strength of upper limbs (dynamometry of strong and weak arm) is related with cyclist's ability to make contact with the bike effortlessly. The average value of these two indexes is as follows: $x=27,45 \pm 0,45 \mathrm{~kg}$ for the first, and $x=26,05$ $\pm 0,57 \mathrm{~kg}$ for the second. The results distraction ranges between 4 and $8 \%$ and shows high level of uniformity of the studied group in the begging of our research regarding isometric strength of upper limbs. As mentioned above, these two indexes are key to the riding technique in cycling sports.

The index presenting flexibility have average value of $x=6,9 \pm 1,03 \mathrm{~cm}$ and logically has the highest coefficient of variance $(\mathrm{v}=15 \%)$ from all studied indexes for this age group.

The two anthropometric indexes (height and weight) have average values of $X=166,55 \pm 3,93 \mathrm{~cm}$ for the first, and $x=57,55 \pm 0,65 \mathrm{~kg}$ for the second, and variance coefficients of $\mathrm{V}=2,35 \%$ for height and $\mathrm{V}=3,4 \%$ for weight. This determines the high level of homogeneity of the studied population (15-16-years-old) in terms of physical development of young cyclists, which is of great importance due to the fact that during this age period the coaches 
main task is to achieve preliminary sport orientation towards a certain cycling discipline.

For confirming the statistical reliability of the sport selection set of tests for the studied age period, a second test was conducted. The results from the variance analysis are presented in Table 2 and those from the correlation analysis are presented in Table 3.

What is specific for this age group: correlation $r_{t t}=0,74$ at $\alpha \leq 0,00$, which means that this test has a moderate degree of reliability and probability. In the $30 \mathrm{~m}$ from standing start test, the correlation coefficient is $r_{t t}=0,91$ at $\alpha \leq 0,00$ and high degree of reliability during repeated studies. The coefficients of uncertainty are respectively $\mathrm{k}^{2}=56 \%$ for the first and $\mathrm{k}^{2}=18 \%$ for the second index, especially for the second it means high reproducibility in repeated researches.

Table 2. Variance analysis of studied indexes from the second testing-age group 15-16-year old cyclists.

\begin{tabular}{|l|c|c|c|c|c|c|c|c|}
\hline \multicolumn{1}{|c|}{ Index } & $\begin{array}{c}\text { Mea- } \\
\text { sured in: }\end{array}$ & $\mathbf{R}$ & $\mathbf{m i n}$ & $\mathbf{m a x}$ & $\mathbf{X}$ & $\mathbf{m}_{\mathbf{x}}$ & $\mathbf{S}$ & $\begin{array}{c}\mathbf{V} \\
\mathbf{( \% )}\end{array}$ \\
\hline 30 m from crouch start & $\mathrm{s}$ & 0,42 & 4,64 & 5,06 & 4,86 & 0,02 & 0,10 & 2,05 \\
\hline 30 m from standing start & $\mathrm{s}$ & 1,12 & 3,76 & 4,88 & 4,14 & 0,06 & 0,30 & 7,20 \\
\hline $\mathbf{1 0 0}$ m from flying start & $\mathrm{s}$ & 2,20 & 5,24 & 7,94 & 6,40 & 0,13 & 0,61 & 9,05 \\
\hline 200 m from flying start & $\mathrm{s}$ & 3,92 & 11,59 & 15,51 & 12,86 & 0,22 & 0,99 & 7,70 \\
\hline 500 m starting from place & $\mathrm{s}$ & 4,55 & 35,69 & 40,24 & 37,28 & 0,30 & 1,35 & 3,62 \\
\hline $\mathbf{1 0 0 0}$ m starting from place & $\mathrm{s}$ & 4,00 & 71,22 & 75,22 & 72,93 & 0,21 & 0,95 & 1,30 \\
\hline 2000 m starting from place & $\mathrm{s}$ & 16,20 & 160,16 & 176,36 & 167,38 & 1,09 & 4,87 & 2,90 \\
\hline Dynamometry - strong hand & $\mathrm{kg}$ & 5,00 & 45,00 & 50,00 & 48,09 & 0,29 & 1,31 & 2,72 \\
\hline Dynamometry - weak hand & $\mathrm{kg}$ & 3,00 & 45,00 & 48,00 & 46,40 & 0,25 & 1,14 & 2,45 \\
\hline Flexibility & $\mathrm{cm}$ & 3,80 & 6,20 & 10,00 & 8,08 & 0,23 & 1,03 & 12,74 \\
\hline Height & $\mathrm{m}$ & 14,00 & 164,00 & 178,00 & 170,11 & 0,87 & 3,89 & 2,30 \\
\hline Standing long jump & $\mathrm{cm}$ & 0,29 & 2,25 & 2,54 & 2,38 & 0,02 & 0,09 & 3,70 \\
\hline Weight & $\mathrm{kg}$ & 11,00 & 54,00 & 65,00 & 60,73 & 0,77 & 3,46 & 6,00 \\
\hline Vertical jump & $\mathrm{cm}$ & 13,00 & 37,00 & 50,00 & 43,74 & 0,78 & 3,50 & 8,00 \\
\hline
\end{tabular}

In the $200 \mathrm{~m}$ flying start test the correlation coef- means that objectively this is the age group at which ficient is $r_{t t}=0,90$ for $a \leq 0,00$ and the reproduc- it can be used as the primary criteria for sport seibility factor (uncertainty) $\mathrm{k}^{2}=25 \%$. This test has a lection of cyclists and provides information on the high degree of reliability at this age, as opposed to start reaction and the maximum speed abilities on 11-12-year-olds and 15-16-year-olds. This probably short distances.

Table 3. Statistical reliability of studied indexes of 15-16-year-old cyclists.

\begin{tabular}{|l|c|c|c|c|}
\hline \multicolumn{1}{|c|}{ Index } & Measured in: & $\mathbf{r}_{\text {tt }}$ & $\boldsymbol{\alpha} \leq \mathbf{0 , 0 1}$ & $\mathbf{k}^{\mathbf{2}} \mathbf{0}$ \\
\hline 30 m from crouch start & $\mathrm{s}$ & 0,75 & 0,00 & 56 \\
\hline 30 m from standing start & $\mathrm{s}$ & 0,91 & 0,00 & 18 \\
\hline $\mathbf{1 0 0}$ m from flying start & $\mathrm{s}$ & 0,91 & 0,00 & 18 \\
\hline $\mathbf{2 0 0}$ m from flying start & $\mathrm{s}$ & 0,90 & 0,00 & 81 \\
\hline $\mathbf{5 0 0}$ m starting from place & $\mathrm{s}$ & 0,92 & 0,00 & 16 \\
\hline $\mathbf{1 0 0 0}$ m starting from place & $\mathrm{s}$ & 0,87 & 0,00 & 25 \\
\hline $\mathbf{2 0 0 0}$ m starting from place & $\mathrm{s}$ & 0,40 & 0,08 & 84 \\
\hline Dynamometry - strong hand & $\mathrm{kg}$ & 0,90 & 0,00 & 19 \\
\hline Dynamometry - weak hand & $\mathrm{kg}$ & 0,85 & 0,00 & 28 \\
\hline Flexibility & $\mathrm{cm}$ & 0,86 & 0,00 & 23 \\
\hline Height & $\mathrm{m}$ & 0,96 & 0,00 & 8 \\
\hline Standing long jump & $\mathrm{cm}$ & 0,95 & 0,00 & 10 \\
\hline Weight & $\mathrm{kg}$ & 0,88 & 0,00 & 23 \\
\hline Vertical jump & $\mathrm{cm}$ & 0,96 & 0,00 & 8 \\
\hline
\end{tabular}


For the $100 \mathrm{~m}$ flying start test, the correlation coefficient is $r_{t t}=0,91$, for $\alpha \leq 0,00$ and the reproducibility coefficient (uncertainty) $\mathrm{k}^{2}=18 \%$.

In the $500 \mathrm{~m}$ test, the correlation coefficient if very high $\left(r_{t t}=0,98\right.$, at $\left.\alpha \leq 0,00\right)$, which shows its high statistical reliability and supports the reason to be include in the test battery for sport selection and orientation of young cyclists. Reproducibility coefficient (uncertainty) is $\mathrm{k}^{2}=16 \%$.

In the test $1000 \mathrm{~m}$ and $2000 \mathrm{~m}$ starting from place the correlation coefficients are respectively $r_{\mathrm{tt}}=0,87$ at $\alpha \leq 0,00$ and $r_{t t}=0,40$ at $\alpha \leq 0,00$. The first one is highly informative and reliable, while the latter have low-reliability and must be removed from the test battery because the combination of speed and strength carries information which requires a high level of training that young cyclists do not possess at this age. The same is confirmed by the coefficient of uncertainty $-\mathrm{k}^{2}=25 \%$ and $\mathrm{k}^{2}=84 \%$.

The tests carrying information for the isometric strength of the upper limbs have a statistical reliability $\left(r_{t t}=0,90\right.$ at $\alpha \leq 0,00$ and $r_{t t}=0,85$ at $\left.\alpha \leq 0,00\right)$ and reproducibility $\left(\mathrm{k}^{2}=19 \%\right.$ and $\left.\mathrm{k}^{2}=28 \%\right)$. Therefore, it is perfectly natural to define them as important in the sport selection of young cyclists.

The flexibility test for this age group has high statistical reliability $\left(\mathrm{r}_{\mathrm{tt}}=0,86\right.$ at $\alpha \leq 0,00$ and $\left.\mathrm{k}^{2}=23 \%\right)$.

The standing long jump and the vertical jump tests show a high degree of statistical reliability $\left(\mathrm{r}_{\mathrm{tt}}=0,95\right.$ at $\alpha \leq 0,00$ and $r_{t t}=0,96$ at $\left.\alpha \leq 0,00\right)$. This is confirmed by the coefficients of uncertainty $-\mathrm{k}^{2}=10 \%$ and $\mathrm{k}^{2}=8 \%$.

The two anthropometric indexes (height and weight) for the 15-16-year-old have high level of statistical reliability $\left(r_{\mathrm{tt}}=0,96\right.$ at $\alpha \leq 0,00$ and $\mathrm{r}_{\mathrm{tt}}=0,88$ at $\alpha \leq 0,00$ ), which is confirmed by the values of uncertainty coefficients $\left(\mathrm{k}^{2}=8 \%\right.$ for height and $\mathrm{k}^{2}=23 \%$ for weight). They complement the test battery and can serve as a guideline for the sport selection and orientation of young cyclists.

\section{CONCLUSION}

The analyzed initial results give us a reason to claim that the obtained information for statistical reliability of tests included in the battery for 15-16-yearold cyclists is correct and therefore they have been chosen correctly.

The results of the conducted survey can be used to update the training process in cycling, by specifying and individualizing the training parameters.

\section{REFERENCES}

Dimitrova, D. (2001). Fizicheska deesposobnost na podrastvashti $\mathrm{v}$ vrazka $\mathrm{s}$ vazrastovite promeni $\mathrm{v}$ telesnite razmeri I sastava na telesnata masa. Disertacionen trud, NSA, Sofia // Димитрова, Д. (2001). Физическа дееспособност на подрастващи във връзка с възрастовите промени в телесните размери и състава на телесната маса. Дис. труд, НСА, София. Doychev, P. (2019). Esenciata $v$ koloezdeneto. Avangard Prima. Sofia. // Дойчев, П. (2019). Есенцията в колоезденето. Авангард Прима. София.

Kolev, I. (2016). Osnovi na podbora I orientaciata v koloezdeneto. Doctorski trud, NSA, Sofia. // Колев, И. (2016). Основи на подбора и ориентацията в колоезденето. Докторски труд, НСА, София.

Doychev, P., Kolev, I., Ilinova, B. (2009). Specifics of the structure and the content of the training of the junior cyclists in the competition period. International Congress of educational research, Canakkale 